\title{
L-ASCORBIC ACID, $\beta$-CAROTENE AND LYCOPENE CONTENT IN PAPAYA FRUITS (Carica papaya) WITH OR WITHOUT PHYSIOLOGICAL SKIN FRECKLES
}

\author{
Leandro Marelli de Souza ${ }^{1 *}$; Karla Silva Ferreira ${ }^{1}$; José Benício Paes Chaves²; Sílvio Lopes \\ Teixeira $^{3}$ \\ ${ }^{1}$ UENF - Lab. de Tecnologia de Alimentos, Av. Alberto Lamego, 2000 - 28013-602 - Campos dos Goytacazes, RJ - \\ Brasil. \\ ${ }^{2} U F V$ - Depto. de Tecnologia de Alimentos, Av. P. H. Rolfs, s/n - 36570-000 - Campus Universitário - Viçosa, \\ $M G$ - Brasil. \\ ${ }^{3}$ UENF - Lab. de Fitotecnia, Av. Alberto Lamego, 2000 - 28013-602 - Campos dos Goytacazes, RJ - Brasil. \\ *Corresponding author <marelli@uenf.br>
}

\begin{abstract}
The Skin Freckles is a papaya skin disorder that depreciates de fruit appearance and hampers its commercialization, although not lowering its nutritive value. Being the papaya a good source of ascorbic acid, $\beta$-carotene and licopene this research aimed at determining L-ascorbic acid, $\beta$-carotene and licopene content in papaya fruits, from 'Formosa' and 'Solo' group varieties, with and without apparent physiological skin disease (skin freckles). Fruits were harvested in the Southeast Region of Brazil. L-ascorbic acid content was determined by titration technique. $\beta$-carotene and licopene contents were determined by high performance liquid chromatography technique (HPLC). L-ascorbic

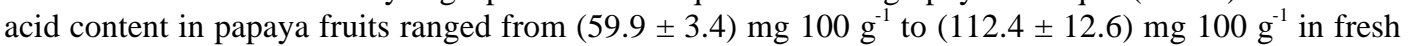



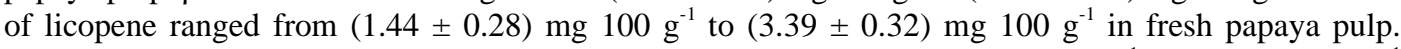
L-ascorbic acid contents of papaya fruits with skin disease averaged $7.0 \mathrm{mg} 100 \mathrm{~g}^{-1}$ to $10.0 \mathrm{mg} 100 \mathrm{~g}^{-1}$ higher than those of papaya fruits without skin freckles $(P<0.05)$.
\end{abstract}

Key words: Brazil, fruits composition, carotenoids, vitamin $\mathrm{C}$, food composition

\section{CONTEÚDO DE ÁCIDO L-ASCÓRBICO, $\beta$-CAROTENO E LICOPENO EM FRUTOS DE MAMÃO (Carica papaya) COM E SEM MANCHA FISIOLÓGICA}

\begin{abstract}
RESUMO: A Mancha Fisiológica do Mamão (MFM) é uma desordem da casca do mamão, que deprecia a aparência do fruto e prejudica a sua comercialização, embora não prejudique o seu valor nutritivo. Considerando ser o mamão, uma boa fonte de ácido L-ascórbico, $\beta$-caroteno e licopeno, esta pesquisa visou determinar o índice destes componentes em frutas de mamão, das variedades do grupo 'Formosa' e 'Solo', com e sem Mancha Fisiológica do Mamão (MFM) aparente na pele. As frutas foram colhidas na região do sudeste de Brasil. O teor de ácido L-ascórbico foi determinado pela técnica de titulação. Os índices do $\beta$-caroteno e do licopeno foram determinados pela técnica de cromatografia líquida de alta eficiência (HPLC). O teor de ácido L-ascórbico variou de $(59,9 \pm 3,4) \mathrm{mg} 100 \mathrm{~g}^{-1}$ a $(112,4 \pm 12,6) \mathrm{mg}^{100 \mathrm{~g}^{-1}}$ de polpa fresca de mamão. O teor de $\beta$-caroteno variou de $(0,19 \pm 0,07) \mathrm{mg} 100 \mathrm{~g}^{-1}$ a $(0,56 \pm 0,09) \mathrm{mg} 100$

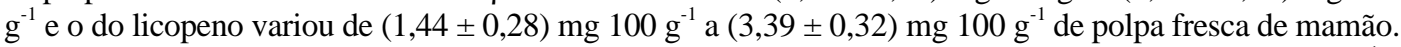
Os índices de ácidos L-ascórbico na polpa dos frutos de mamão com MFM variaram de 7,0 mg $100 \mathrm{~g}^{-1} \mathrm{a}$ $10,0 \mathrm{mg} 100 \mathrm{~g}^{-1}$ a mais do que os teores encontrados na polpa dos frutos de mamão sem a $\operatorname{MFM}(P<0,05)$. Palavras-chave: Brasil, composição de frutas, carotenoides, vitamina $\mathrm{C}$, composição de alimentos
\end{abstract}

\section{INTRODUCTION}

Among several substances from Carica papaya fruits chemical composition there are those with antioxidant activity, for example, as the carotenoids and L-ascorbic acid. $\beta$-carotene is the main carotenoid with pro-vitamin A activity (Olson, 1996).
Multiple functions are attributable to L-ascorbic acid in humans. It is important for its buffer function in oxidation reduction processes, but also because of its molecular structure particularities in its ability for ions and hydrogen electrons transfer in reversible processes. L-ascorbic acid has an important role in corticoids and catecholamines biosynthesis and also par- 
ticipate in bone, teeth and blood synthesis and maintenance (Levine et al., 1997). Adult Recommended Dietary Allowance (RDA) for L-ascorbic acid is $45 \mathrm{mg}$ (FAO, 2003). Physiological papaya fruit skin disease present as skin freckles, gray or brown in color, ranging from very small points to $10 \mathrm{~mm}$ diameter dark halos. This disease, which is reported to occur in all papaya producing countries, decreases the fruit appearance, which lower its commercial value. It has been observed in fruits over 40 days after anthese, being more apparent as the fruits become more developed, closer to harvesting stage (Ventura et al., 2003). In South Africa, papaya skin freckles is reported to occur mainly on fruits developing in those months with soil water deficiency and lower whether temperature, from April to July. In the papaya tree, fruits more exposed to sun radiation presented higher intensity of skin freckles (Kaiser et al., 1996).

Papaya fruit skin freckles depreciate fruit appearance and lower its commercial value. In a literature review it has not been found studies on antioxidant compounds contents in papaya fruits. Thus, in this paper the objective was to evaluate L-ascorbic acid, $\beta$-carotene and licopene contents in 'Formosa' and 'Solo' papaya fruits samples with and without skin freckles.

\section{MATERIAL AND METHODS}

Papaya fruit samples from 'Formosa' group, cultivar Tainung 01 (F1 hybrid) were harvested in January 2003 and February 2004. Papaya fruits from 'Solo' group, Golden cultivar, were harvested in March 2003. Thus, there were three harvesting time. Both groups were from commercial crop fields located in Linhares (19 $\left.15^{\circ} \mathrm{S}, 39^{\circ} 51^{\prime} \mathrm{W}\right)$, in Espirito Santo State, Brazil. The production área shows maximum temperatures ranging from $30^{\circ} \mathrm{C}$ to $32^{\circ} \mathrm{C}$ and minimum ones between $15^{\circ} \mathrm{C}$ and $18^{\circ} \mathrm{C}$. Ten fruits with skin freckles and ten fruits without skin freckles from two ripen stage were harvested by hand, totaling 120 fruits. Ripen stage 1 were fruits with $15 \%$ skin surface in yellow color and stage 2 were $25 \%$.

After harvesting, papaya fruits were kept under $25.3 \pm 0.9^{\circ} \mathrm{C}$ temperature and $70.5 \pm 4.7 \%$ relative humidity, until fruits presented $75 \%$ of skin surface typical yellow color. This maturation stage was reached after seven days, for the ripen stage 1, and after six days for the ripen stage two fruits. Papaya fruits had their skin manually removed with a stainless still knife and the seeds were discarded. Fruits were cut longitudinally and transversally, totaling eight pieces per fruit. Two cuts from upper half and two from lower half, each from opposed fruit side, were grained in warring blender. Five grams exact weight of this slurry aliquots were packed in polyethylene bags, and then frozen by liquid nitrogen. After freezing, samples were kept under $-25^{\circ} \mathrm{C}$ frozen storage until time of laboratory analysis for L-ascorbic acid, $\beta$-carotene and licopene content. Each fruit was analyzed separately. Preliminary essays in our laboratory had shown that these storage conditions are adequate to stabilize the substances analyzed in this research.

L-ascorbic acid content was determined by titulometric method with 2.6-dichloroindophenol (AOAC, 1998), with substitution of $10 \%$ metaphosphoric acid by $1 \%$ oxalic acid. This technique has been validated in our laboratory by titrating samples added by $0.5 ; 1.0$ and $1.5 \mathrm{mg} \mathrm{L}$-ascorbic acid and diluted with $10 \%$ metaphosphoric acid or in $5 \%$ or $1 \%$ oxalic acid, with $100 \%$ recovery and not finding any difference among the results, Carotenoid substances extraction in papaya fruit slurry was carried out according to procedures described by Wilberg \& RodriguezAmaya (1995). Papaya fruit slurry was weighted and quantitatively transferred to test tube with about $20 \mathrm{~mL}$ of a ethanol:hexane 1:1 solvent mixture, and homogenized in a blendor. Homogenate was filtered in a vacuum filter system with the help of 0.45 micra pore diameter PTFE membranes for aqueous and organic solvents.

All pulp residue retained in membrane filter were transferred to test tube, by repeating homogenization process, addition of about $20 \mathrm{~mL}$ methanol:hexane 1:1 and filtration running until papaya pulp lose its typical color completely (three times on average). All filtrate material was transferred to a separator funnel added by $20 \mathrm{~mL}$ hexane and $25 \mathrm{~mL}$ distilled water, and then shaked lightly for 30 to $60 \mathrm{sec}-$ onds and left to rest for phases separation. Aqueous phase collected was transferred to a second separator funnel and subjected to two re-extraction procedures by adding $20 \mathrm{~mL}$ ethanol:hexane 1:1 solvent mix, collecting combined hexane phases containing all the carotenoid substances. Aqueous residue had been removed from hexane phase by adding about $1.0 \mathrm{~g}$ of sodium sulfate anhydride $\left(\mathrm{Na}_{2} \mathrm{SO}_{4}\right)$ and then shaked manually for 30 seconds. All hexane carotenoid extract content were removed to $250 \mathrm{~mL}$ flat bottom balloons and concentrated by vacuum rotary evaporator at about $40^{\circ} \mathrm{C}$, for 25 minutes. After concentration, samples were recovered in hexane, and then transferred to brown color volumetric balloons, and the exact volume completed with hexane.

Carotenoid content was determined by High Performance Liquid Chromatography in a SPD-10 AV Shimadzu UV-VIS instrument, UV-Visible spectrophotometry detector, at $470 \mathrm{~nm}$; Shimadzu injector, 
equipped with $20 \mu \mathrm{L}$ loop; SUPERCOSIL ${ }^{\mathrm{TM}} \mathrm{LC}-18 \mathrm{mi}-$ cra, $250 \mathrm{~mm}$ length and $4.6 \mathrm{~mm}$ i.d. column. Acetonytrile:chloroform (92:8) chromatographic grade at $1.5 \mathrm{~mL} \mathrm{~min}^{-1}$ was the mobile phase. Run time for each sample was $25 \mathrm{~min}$. All chemicals used in the mobile phase were vacuum filtered in a PTFE membrane system, modified for organic and aqueous solvents, with 0.45 micra diameter pores. Mobile phase chemicals and samples were degassed in an ultrasonic washer. The Standard used by HPCL of $\beta$-carotene or licopene of Sigma trade. The $\beta$-carotene synthetic pure $95 \%$ and licopene $90-95 \%$. The pack contents licopene $(1.0 \mathrm{mg})$ and pack $\beta$-carotene, was transfer to balloon volumetric to the dark color and full by 30 $\mathrm{mL}$ of hexane HPCL of Sigma trade. A $1.0 \mathrm{mcg}$ to $12.0 \mathrm{mcg}$ of $\beta$-carotene and $10.0 \mathrm{mcg}$ to $50.0 \mathrm{mcg}$ of licopene was used, divided in five points, by standard curve. Had response lineal with $\mathrm{R}^{2} 0.99$ by both $\beta$-carotene and licopene. Analysis were carried out by injecting $1.0 \mathrm{~mL}$ of $\beta$-carotene or licopene standard solutions in hexane and $1.0 \mathrm{~mL}$ of samples in the chromatograph, with a $3.0 \mathrm{~mL}$ disposable syringe. Figure 1 presents typical HPLC chromatograms of the standard $\beta$-carotene (a) and lycopene (b). Extraction and chromatograph injection steps were done in the same day under low light.

Experimental design was completely randomized in a factorial arrangement, with ten replications (fruits). The fruits were sampled, harvested and evaluated at two ripen stages (F2), with and without apparent physiological skin freckles (F1). Thus, there were 40 fruits from hybrid Tainung 01 harvested in January 2003, 40 papaya fruits from the same hybrid harvested in February 2004 and 40 papaya fruits from 'Solo' group, Golden cultivar harvested in March 2003, totaling 120 fruits analyzed or 120 sample units. Among the 40 fruits harvested for each group, 10 were with freckles in maturation stage 1,10 with freckles in maturation stage 2, 10 without freckles in maturation stage 1 and 10 without freckles in maturations stage 2 .

The data were subjected to analysis of variance (ANOVA) at significance level a of 0.05 .

\section{RESULTS AND DISCUSSION}

Papaya fruits with skin freckles had higher


fruits without skin freckles, $75.9 \mathrm{mg} 100 \mathrm{~g}^{-1}(P \leq 0.05)$ (Table 1.). Sample ranged from 7.0 to $10.0 \mathrm{mg} 100$ $\mathrm{g}^{-1}$ of papaya pulp, except for that from hybrid Tainung 01 ('Formosa') at ripen stage 2, harvested in February 2004. This result can be attributed to a low incidence of skin freckles presented in this fruits.


Figure 1 - Typical HPLC chromatograms of the standard $\beta$ carotene (a), lycopene (b), and carotenoids in papaya (c).

L-ascorbic acid levels observed in this research are similar to others reported in the literature. Oliveira (1999) reported $86.0 \mathrm{mg} 100 \mathrm{~g}^{-1}$ of L-ascorbic acid in Improved Sunrise Solo Line papaya fruits and 73.8 mg $100 \mathrm{~g}^{-1}$ in Tainung 01/781 hybrid, both determined at the seventh day after harvesting. Souza (1998) re-

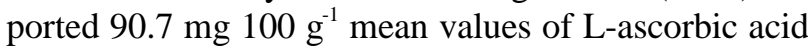
in Sunrise Solo 783 papaya fruits and $71.3 \mathrm{mg} 100 \mathrm{~g}^{-1}$ in Tainung 01 hybrid. Islam et al. (1993) analyzed papaya fruit samples from five group cultivars and reported L-ascorbic acid mean values ranging from 88

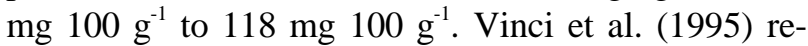
ported L-ascorbic acid mean values of $88 \mathrm{mg} 100 \mathrm{~g}^{-1}$

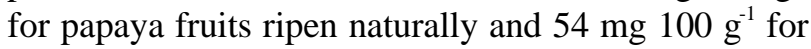
fruits artificially ripen.

Mean values and standard deviation for $\beta$-carotene and lycopene are presented in Table 2 and typical HPLC chromatograms of the standard carotenoids 
Table 1 - L-ascorbic acid mean values in $\mathrm{mg} 100 \mathrm{~g}^{-1}$ fresh papaya pulp from 'Formosa' and 'Solo' groups, with and without skin freckles (SF) harvested in two ripen stage, in January 2003, February 2004 and March 2003.

\begin{tabular}{lccc}
\hline Cultivar & Ripen stage & With SF & Without SF \\
\hline & 1 & $70.2 \pm 8.7^{*}$ & $63.0 \pm 10.0^{*}$ \\
$\begin{array}{l}\text { Tainung 01 'Formosa' } \\
\text { harvest 01/17/2003 }\end{array}$ & 2 & $77.8 \pm 10.9^{*}$ & $68.2 \pm 9.7 *$ \\
\hline $\begin{array}{l}\text { Tainung 01 'Formosa' } \\
\text { harvest 02/06/2004 }\end{array}$ & 1 & $67.9 \pm 6.7 *$ & $59.9 \pm 6.1^{*}$ \\
\hline $\begin{array}{l}\text { Golden 'Solo' harvest } \\
\text { 03/21/2003 }\end{array}$ & 1 & $59.9 \pm 3.4^{*}$ & $60.3 \pm 4.2^{*}$ \\
\hline Mean & 2 & $111.0 \pm 14.6^{*}$ & $101.4 \pm 8.1 *$ \\
\hline
\end{tabular}

*Mean values for ten papaya fruits \pm standard deviation. $* *$ Mean values for sixty papaya fruits \pm standard deviation. Different letters are different at the $5 \%$ by $\mathrm{F}$ test.

Table 2 - Lycopene and $\beta$-carotene mean values in papaya pulp from 'Formosa' and 'Solo' groups, with and without skin freckles harvested in two ripen stage, in January 2003, February 2004 and March 2003.

\begin{tabular}{|c|c|c|c|c|}
\hline Cultivar & Ripen stage & Skin freckles & Lycopene & $\beta$-carotene \\
\hline \multirow{5}{*}{$\begin{array}{l}\text { Tainung } 01 \text { 'Formosa' } \\
\text { harvest } 01 / 17 / 03\end{array}$} & \multirow{3}{*}{1} & \multicolumn{3}{|c|}{$\left(\text { mg } 100 \mathrm{~g}^{-1}\right)^{\mathrm{a}}$} \\
\hline & & With & $1.57 \pm 0.49$ & $0.31 \pm 0.11$ \\
\hline & & Without & $2.49 \pm 0.56$ & $0.51 \pm 0.06$ \\
\hline & \multirow{2}{*}{2} & With & $2.85 \pm 0.47$ & $0.56 \pm 0.09$ \\
\hline & & Without & $2.61 \pm 0.76$ & $0.48 \pm 0.12$ \\
\hline \multirow{4}{*}{$\begin{array}{l}\text { Tainung } 01 \text { 'Formosa' } \\
\text { harvest } 02 / 06 / 04\end{array}$} & \multirow{2}{*}{1} & With & $2.51 \pm 0.41$ & $0.34 \pm 0.09$ \\
\hline & & Without & $2.22 \pm 0.41$ & $0.22 \pm 0.09$ \\
\hline & \multirow{2}{*}{2} & With & $3.39 \pm 0.32$ & $0.23 \pm 0.07$ \\
\hline & & Without & $2.94 \pm 0.79$ & $0.19 \pm 0.07$ \\
\hline \multirow{4}{*}{$\begin{array}{l}\text { Golden 'Solo' harvest } \\
03 / 21 / 03\end{array}$} & \multirow{2}{*}{1} & With & $1.44 \pm 0.28$ & $0.33 \pm 0.11$ \\
\hline & & Without & $1.50 \pm 0.23$ & $0.34 \pm 0.13$ \\
\hline & \multirow{2}{*}{2} & With & $1.70 \pm 0.30$ & $0.48 \pm 0.09$ \\
\hline & & Without & $1.51 \pm 0.31$ & $0.46 \pm 0.08$ \\
\hline
\end{tabular}

${ }^{a}$ Mean values for ten papaya fruits \pm standard deviation.

in papaya in the Figure 1(c). Analysis of variance did not detected difference $(P \geq 0.05)$ in lycopene or $\beta$ carotene mean values between papaya fruits with and without skin freckles. Mean $\beta$-carotene values ranged from $(0.19 \pm 0.07) \mathrm{mg} 100 \mathrm{~g}^{-1}$ to $(0.56 \pm 0.09) \mathrm{mg}$ $100 \mathrm{~g}^{-1}$ fresh papaya pulp. Lower $\beta$-carotene values were observed in 'Formosa' Tainung 01 papaya fruits without skin freckles, harvested in February 2004 and higher $\beta$-carotene values were detected in papaya fruits with physiological skin freckles harvested in January 2003. Rodriguez-Amaya (1996) observed differences in $\beta$-carotene content in papaya fruits produced in different Brazilian States. Papaya fruit samples from Sao Paulo State presented $\beta$-carotene mean values of $(0.14$ $\pm 0.05) \mathrm{mg}_{100 \mathrm{~g}^{-1}}$ fresh pulp and fruits from Bahia State were $(0.61 \pm 0.14) \mathrm{mg} 100 \mathrm{~g}^{-1}$. Weather condi- tions, ripen stage, variety or group cultivar, geographical area and season of the year are important for carotenoid levels in fruits (Setiawan et al., 2001).

Papaya as a fruit can be considered as a moderate source of Provitamin A, ranging from $82 \mu \mathrm{g}$ to $190 \mu \mathrm{g}$ Retinol Equivalent (RE) $100 \mathrm{~g}^{-1}$ fresh pulp, when including the $\beta$-criptoxantine contribution Rodriguez-Amaya (1996). Overall mean value for $\beta$ carotene observed in our research was $0.37 \mathrm{mg} 100$ $\mathrm{g}^{-1}$ fresh pulp, which is $62 \mu \mathrm{g}$ RE $100 \mathrm{~g}^{-1}$ fresh papaya pulp. This represents $6.2 \%$ of World Health Organization Recommended Daily Allowance (RDA) for adult people, which is $1.000 \mu \mathrm{g}$ (FAO, 2003).

Lycopene mean value was $2.23 \mathrm{mg} 100 \mathrm{~g}^{-1}$. Lower mean value was $(1.44 \pm 0.28) \mathrm{mg} 100 \mathrm{~g}^{-1}$ for cv. Golden ('Solo') and higher value was (3.39 \pm 0.32 ) 
mg $100 \mathrm{~g}^{-1}$ for Tainung 01 hybrid. Setiawan et al. (2001) reported $5.75 \mathrm{mg} 100 \mathrm{~g}^{-1}$ fresh pulp lycopene mean value in papaya from Indonesia. Kimura et al. (1991) reported lycopene mean value of $(2.10 \pm 1.60)$ mg $100 \mathrm{~g}^{-1}$ fresh pulp in papaya fruits from 'Solo' group produced in Bahia State. She also observed licopene mean value of $(1.90 \pm 0.40) \mathrm{mg} 100 \mathrm{~g}^{-1}$ in 'Formosa' group papaya fruits produced in Sao Paulo Sate and $(2.60 \pm 0.30) \mathrm{mg} 100 \mathrm{~g}^{-1}$ for those produced in Bahia State. Lycopene was the main carotenoid in papaya fruits evaluated in this research. This is in agreement with reports by Wilberg \& RodriguezAmaya (1995), Kimura et al. (1991) and Setiawan et al. (2001).

Lycopene does not have Vitamin A activity but contribute to papaya pulp reddish color. Golden papaya fruit pulp reddish color was less intense than that for Tainung 01 hybrid and this may be due to its lower content in lycopene, which ranged from $(1.44 \pm 0.28)$ $\mathrm{mg} 100 \mathrm{~g}^{-1}$ to $(1.70 \pm 0.30) \mathrm{mg} 100 \mathrm{~g}^{-1}$ fresh papaya pulp.

Tomatoes are considered good source of lycopene, with average ranging from 3.0 to $5.0 \mathrm{mg} 100$ $\mathrm{g}^{-1}$ fresh pulp. Research had shown that consumption of food products containing tomatoes reduce the possibility of developing several types of cancer, which has been associated to higher blood lycopene levels (Shi $\&$ Maguer, 2000). Lycopene levels in papaya fruit are close to that of tomatoes. Thus it can also be considered as a good source of this carotenoid.

\section{CONCLUSIONS}

L-ascorbic acid content in papaya 'Formosa' group fruits ranged from $(59.9 \pm 3.4) \mathrm{mg} 100 \mathrm{~g}^{-1}$ to $(70.2 \pm 8.7) \mathrm{mg} 100 \mathrm{~g}^{-1}$. $\beta$-carotene mean values


$\mathrm{mg} 100 \mathrm{~g}^{-1}$ and licopene levels ranged from (3.39 \pm $0.32) \mathrm{mg} 100 \mathrm{~g}^{-1}$ to $(1.57 \pm 0.49) \mathrm{mg} 100 \mathrm{~g}^{-1}$. Analysis of variance did not detect difference in licopene or $\beta$-carotene mean values between papaya fruits with and without skin freckles, but L-ascorbic acid levels in papaya fruits with physiological skin freckles were, on average, $7.2 \mathrm{mg} 100 \mathrm{~g}^{-1}$ higher that in fruits without the disease $(P \leq 0.05)$.

\section{ACKNOWLEDGEMENTS}

To FINEP and FAPERJ for the financial support.

\section{REFERENCES}

ASSOCIATION OF OFFICIAL ANALYTICAL CHEMISTS AOAC. Official methods of analyses. $16 \mathrm{ed}$, Washington, DC: AOAC, 1998. v.1, p.16-18.

FOOD AND AGRICULTURE ORGANIZATION - FAO. Diet, nutrition and the prevention of chronic diseases. Geneva, 2003. (WHO Techinical Report Series, 916). Available at: http:// apps.fao.org. Accessed 06 Nov. 2005.

ISLAM, M.N.; COLON, T.; VARGAS, T. Effect of prolonged solar exposure on the vitamin $\mathrm{C}$ contents of tropical fruits. Food Chemistry, v.48, p.75-78, 1993.

KAISER, C.; ALlAN, P.; WHITE, B.J.; DEHRMANN, F.M. Some morphological and physiological aspects of freckle on papaya (Carica papaya L.) fruit. Journal of South African Society for Horticulture Science, v.6, p.37- 41, 1996.

KIMURA, M.; RODRIGUEZ-AMAYA, D.B.; YOKOYAMA, S.M. Cultivar differences and geographic effects on the carotenoid composition and vitamin A value of papaya. LebensmittelWissenschaft und Technologie, v.24, p.415-418, 1991.

LEVINE, M.; RUMSEY, S.; WANG, Y.; PARK, J.; KWON, O.; XU, W.; AMANO, N. Vitamina C. In: ZIEGLER, E.E.; FILER JR., L.J. (Ed.) Conocimientos actuales sobre nutrición. 7.ed. Washington, DC: ILSI/OPS, 1997. cap.15, p.155-169.

OLIVEIRA, M.A.B. Variações de algumas características fisiológicas dos frutos de mamoeiro (Carica papaya L.) em função de diferentes épocas de colheita. Campos dos Goytacazes: UENF/ CCTA, 1999. 73p. (Livre-Docência).

OLSON, J. Carotenoid, vitamin A and cancer. Journal of Nutrition, v.116, p.1127-1130, 1996.

RODRIGUEZ-AMAYA, D.B. Assessment of the provitamin A contents of foods - the brazilian experience. Journal of Food Composition and Analysis, v.9, p.196-230, 1996.

SETIAWAN, B.; SULAEMAN, A.; GIRAUD, D.W.; DRISKELL, J.A. Carotenoid content of selected Indonesian fruits. Journal of Food Composition and Analysis, v.14, p.169-166, 2001.

SHI, J.; MAGUER, M.L. Lycopene in tomatoes: chemical and physical properties affected by food processing. Critical Reviews in Biotechnology, v.20, p.293-334, 2000.

SOUZA, G. Características físicas e sensoriais do fruto de cinco cultivares de mamoeiro (Carica papaya L.) produzidas em Macaé - RJ. Campos dos Goytacazes: UENF/CCTA, 1998. 68p. (LivreDocência).

VENTURA, J.A.; COSTA, H.; TATAGIBA, J. S. Manejo das doenças do mamoeiro. In: Martins, D.S.; Costa, A.F.S. (Ed.) A cultura do mamoeiro: tecnologias de produção. Vitória: Incaper, 2003. p.231-308.

VINCI, G.; BOTRE, F.; MELE, G.; RUGGIERI, G. Ascorbic acid in exotic fruits: a liquid chromatographic investigation. Food Chemistry, v.53, p.211-214, 1995.

WILBERG, V.C.; RODRIGUEZ-AMAYA, D.B. HPLC: quantitation of major carotenoids of fresh and processed guava, mango and papaya. Lebensmittel-Wissenschaft und Technologie, v.28, p.474-480, 1995.
Received February 06, 2007

Accepted November 08, 2007 